\title{
O RITMO NA POESIA DE AMORIM DE CARVALHO
}

\author{
Por \\ Júlio Amorim De CARVAlho \\ Ao meu filho José Nilo \\ que -como seu avô Amorim de Carvalho- \\ é homem de generosos sentimentos, \\ de vontade firme, de justo pensamento.
}

\section{I.-Obra poética e versificação: generalidades}

CRIAÇÃO poética de Amorim de Carvalho prolonga-
se praticamente por toda a sua vida, desde a primeira
adolescência até aos últimos meses da terrena existência. As mais antigas poesias que conhecemos datam de 1919 (tinha o poeta quinze anos de idade), muitas das quais foram publicadas em periódicos; o último livro editado em vida ( $A$ comédia da morte, edição tirada a stêncil, distribuída pelo autor) saiu em Paris, no mês de fevereiro de 1976, poucas semanas antes do poeta morrer $^{1}$. De toda essa produção poética pretendemos estudar, apenas, a que Amorim de Carvalho reúniu nos seis volumes da Obra poética escolhida, e a que, não tendo sido neles inserida, foi publicada nos livros Bárbaros. Sonetos (1927), Destino. (Inéditos e dispersos) (1939) e Verbo doloroso. (Inéditos e dispersos) (1942). Interessar-nos-emos unicamente

\footnotetext{
${ }^{1}$ Este poema foi posteriormente publicado na Obra poética escolhida. Vol. III. A comédia da morte e outros poemas (Lisboa, 1979). Os outros volumes da Obra poética escolhida são: Vol. I. Elegia heróica e outros poemas, Vol. II. A erotíada e outros poemas (Porto, 2004), Vol. IV. Il Poverello e outros poemas, Vol. V. Com Deus ou sem Deus e outros poemas, Vol. VI. O apóstolo e outros poemas.
} 
pelas formas definitivas dos ritmos das poesias e dos poemas incluídos por Amorim de Carvalho nos nove volumes da sua obra poética atrás citados; desprezaremos, consequentemente, por agora, o estudo de formas rítmicas anteriores que possam ter sido posteriormente alteradas pelo poeta, cuja análise, comparativa e minuciosa, poderá ficar para outra ocasião ou para outros estudiosos da poesia de Amorim de Carvalho. O conjunto daqueles volumes inclui a sua mais significativa criação poética, -inserindo-se ela na linha da grande poesia de pensamento de expressão portuguesa que vem de Camões e que, depois de Antero e Junqueiro, está representada, com a maior altura, em Pascoaes e Amorim. Uma observação relativa aos Bárbaros e a Destino: aquele livro da juventude e algumas das poesias deste último livro não pertencem ao melhor da poesia amoriniana. Retivémo-los, no entanto, como objecto de análise no presente estudo, por considerarmos que certos versos desses livros já propõem formas rítmicas que serão, com consciência técnica e originalidade, pelo poeta introduzidas ou reintroduzidas na poesia de língua portuguesa.

Há mais uma observação preliminar a fazer. O estudo do ritmo na obra poética de Amorim de Carvalho não poderá ignorar, em muitos aspectos, os seus próprios trabalhos filosóficos e sobre estética, porque -como esteta de séria formação filosófica, com a teoria da arte sistematizada - ele mesmo analisou a técnica versificatória utilizada em sua poesia, e explicou a significação da técnica formal como factor da criação de emoções ${ }^{2}$. Demonstra isso a coerência do pensamento de Amorim de Carvalho, além de uma característica bem própria da sua personalidade, em comparação com a da maior parte dos outros grandes poetas. Por essas razões, teremos de fazer referência a algumas das suas obras, no domínio da estética da literatura. Na versificação, em particular, não podemos, portanto, deixar de seguir a terminologia

2 Sobre os conceitos de técnica formal e técnica conceptual, Vid. a bibliografia de Amorim de Carvalho que incluímos no nosso ensaio subordinado ao título Amorim de Carvalho. No $1 .^{\circ}$ Centenário do seu nascimento. (Síntese biográfica). Uma bibliografia sobre versificação publicado in «Rhythmica. Revista española de métrica comparada» (dirigida por José Domínguez Caparrós e Esteban Torre, editada pela Facultad de filología, Departamento de lengua española, lingüística y teoría de la literatura), Sevilha, ano II, n. ${ }^{\circ} 2,2004$, págs. 16-33. 
fixada por Amorim de Carvalho: porque depois dos seus estudos sobre a teoria do verso -dando à versificação o estatuto de ciência com suas leis e terminologia própria-, já não é lícito referirmo-nos a um vocabulário impreciso, confuso, ou que ficou ultrapassado pelos trabalhos do esteta português. E, se a maior parte dos metricistas persiste ainda em manter-se num como que estado pré-positivo, banhando numa confusão inaceitável de conceitos e terminologias, -não se poderá razoavelmente ignorar o "estado positivo», atingido pela ciência métrica, onde (como disse algures Amorim) se consideram só factos «com as suas leis (relações de constância) e com seu condicionalismo», isto é, onde «há apenas a ideia positiva do como dum facto, que é a lei explicativa do fenómeno»: «facto e lei- o objectivo e o subjectivo em certa recíproca correspondência» que deverá ter, evidentemente, em conta a complexidade própria desse domínio do conhecimento que é o da versificação ${ }^{3}$.

\section{II - O ritmo recitativo nos sonetos de Bárbaros}

Comecemos, pois, pelo primeiro livro de Amorim de Carvalho, publicado em 1927. Bárbaros é constituído por 23 sonetos de motivos exóticos (compostos durante o ano de 1926) nos quais o poeta «procura aparecer-nos com a impassibilidade dum parnasiano, sòmente preocupado com o som, a côr, a luminosidade das suas telas», como escreveu o prefaciador, José Teixeira Rêgo.

13 sonetos foram feitos quase que exclusivamente em versos biexassilábicos (também conhecidos por «alexandrinos») de cesura tónica, indiferentemente sem ou com sinalefa do $1 .^{\circ}$ no $2 .^{\circ}$ hemistíquio ${ }^{4}$. Dois exemplos ao acaso:

\footnotetext{
$\overline{{ }^{3} \mathrm{Cf}}$. Amorim de Carvalho, Teoria geral da versificação. Vol. I. A metrificação e a rima e Vol. II. As estrofes, os sistemas estróficos e a história da versificação (Lisboa, 1987), n. ${ }^{\circ} 65$ («Considerações filosóficas sobre as leis em geral e as leis da versificação em particular»). - A Teoria geral da versificação de Amorim de Carvalho será citada, para diante, com as iniciais: T. g. d. v.

${ }^{4}$ Para os conceitos de cesura e sinalefa, e a noção fundamental de elisão rítmica, Vid. T. g. d. v., vol. I, n. ${ }^{\circ}$ s 2, 7-12. Vid., tb., de Amorim de Carvalho, Problemas da versificação (Lisboa, 1981).
} 
Como estranha bebi|da o fumo entontecia. $6+6$ As densas espirais $\mid-$ eflúvio capitoso $-\quad 6+6$

O ritmo hexassilábico, de acentuação incerta, «de força rítmica mediana», possui toada própria muito maleável e «uma severidade fria que, por vezes, dá como que uma transição entre o verso e a prosa»; na forma composta, a cesura tónica (que é, como dissemos, o modêlo cesural sistematicamente utilizado, em Bárbaros, pelo poeta) abranda aquela severidade ${ }^{5}$. Os biexassílabos estão rigorosamente construídos, excepto num único caso em que nos surge um verso comprimido, ritmicamente contrafeito:

vo-lu-ptuo-sos,-sen-suais,-e-for-tes-co-mo A-tlan-tes

onde as 6 sílabas que se quiz dar ao $10^{\circ}$ hemistíquio tendem a desdobrar-se em 9 (hipertrofia rítmica) ${ }^{6}$ :

vo-lu-pe-tu-o-sos,-sen-su-ais.

Porém, lendo com maior naturalidade, como um composto de base $^{7}$ octossilábica, $8^{4}+6$ :

vo-lu-ptu- $o$-sos,-sen-su-ais, | e fortes como Atlantes ${ }^{8} 8^{4}+6$

a harmonia rítmica da quadra, a que pertence o verso, fica perfeita, conforme a lei das relações matemáticas simples: «Uma sucessão heterométrica de versos agrada ao ouvido se os números dominantes, que exprimem as suas estruturas, têm entre

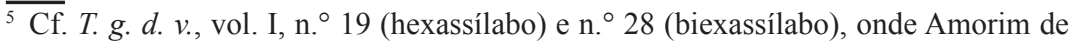
Carvalho faz um muito desenvolvido estudo sobre as características rítmicas e melódicas hexassilábicas.

${ }^{6}$ Hipertrofia rítmica ou ritmos hipertróficos, e versos comprimidos: $T$. g. $d$. v., vol. I, n. ${ }^{\circ}$ s 4,76 .

${ }^{7}$ Conceito de base rítmica nos versos compostos: T. g. $d$. v., vol. I, n. ${ }^{\circ} 24$.

8 Cf., em sentido inverso, os seguintes casos curiosos em Junqueiro: fi-lo-c-se-ra, es-tri-c-ni-na, i-gue-nó-beis, có-c-six - que Amorim de Carvalho recenseou na Introdução à obra poética de Guerra Junqueiro das «Obras de Guerra Junqueiro. (Poesia). Organização e introdução de Amorim de Carvalho». 
si relações matemáticas simples, isto é, se são divisíveis pelo mesmo algarismo» ${ }^{9}$. E terá sido mesmo a agradável combinação do ritmo $8^{4}$ com o 6 (de acentuação incerta em geral, $6^{\infty}$, mas precisamente neste caso, $6^{24}$, com acentuação nas $2 .{ }^{\mathrm{a}} \mathrm{e} 4{ }^{\mathrm{a}}$ sílabas, embora fraca nesta última) que seduziu o autor ${ }^{10}$; recitando este verso, em voz alta certamente, levado pelo excelente acôrdo rítmico entre o octossílabo e o hexassílabo num soneto predominantemente biexassilábico, - deixou passar a ligeira alteração rítmica introduzida, assim, na composição poética:
Nasceram no deserto. As mães, não sabem delas 6+6
Tigres de forma humana e carnes estuantes, $6+6$
voluptuosos, sensuais, e fortes como Atlantes, $8^{4}+6$
fecundam-nas, bramindo, ao clarão das estrelas $6+6$

Não cremos, no entanto, que no primeiro momento de inspiração poética, tivesse Amorim de Carvalho a intenção de, aqui, logo

${ }^{9}$ Vid. T. g. d. v., voI. I, n. ${ }^{\circ}$ s 61-64. Esta lei não é «uma lei do ritmo [como a consideram erradamente diversos autores], mas uma lei da concordância de ritmos, uma lei da relação entre ritmos» para a boa formação de versos compostos irregulares e a boa sucessão de versos heterométricos. Verso é sinónimo de ritmo.

10 Não sendo músico, Amorim de Carvalho possuía um ouvido apuradíssimo para a música e para o ritmo verbal; distinguia matizes, cambiantes sónicos subtilíssimos. A agudeza do seu ouvido, terá sido também uma das condições - e das mais favoráveis - que o levou a interessar-se pela teoria da versificação, alargando as suas perspectivas, pois tinha a aptidão de integrar, sem esforço, ou com pouco esforço, como material útil à sua faculdade de ajuízar, as mais diversas sensações auditivas. Note-se que Amorim de Carvalho viveu, desde a infância, num ambiente bem marcado pelo gôsto da música; diversas pessoas da família próxima tocavam excelentemente piano como sua mãe e avó materna, sua mulher, e a cunhada Maria Amélia esposa do seu irmão Mário; a tradição musical na família do escritor, vinha de longe; no século XIX, o poeta e notável ritmista António Pinheiro Caldas e sua mulher Cândida Carolina Mourão (bisavós de Amorim de Carvalho) deram saraus em sua residência, no Porto, convidando pianistas de nome para tocarem nessas assembleias destinadas a familiares e amigos. Sobre o contexto familial que foi o dos antepassados oitocentistas de Amorim de Carvalho, e o deste intelectual, já no século XX, Vid.: Antonio Pinheiro Caldas, Poesias, 2. ${ }^{a}$ ed., Porto, 1864, notas (págs. 333-364); Júlio Amorim de Carvalho, Dois escritores portuenses. O poeta António Pinheiro Caldas e Amorim de Carvalho, Casa Amorim de Carvalho, Prometeu, Porto, 2000; Id., Achegas para uma biografia: Amorim de Carvalho, "Gil Vicente», Guimarães, IV série, n. ${ }^{\circ} 4$, janeirodezembro de 2003, págs. 62 e segs.; João Manuel Amorim de Carvalho Borges, Maria Amélia Camossa Saldanha Amorim de Carvalho Borges. Seu percurso e contributo para a dimensão histórica da família, ed. do autor, Porto, 2002. 
introduzir esse ritmo composto irregular, de base octossilábica $\left(8^{4}+6\right)$ - mas aceitou-o; e será ele quem, futuramente, com a maior consciência técnica, o utilizará na poesia portuguesa, embora quase sempre nas formas dimétricas seguintes: $8(1)^{4}+6$ com cesura átona, $6+8^{4}$ com cesura tónica, 6(1)+8 também com cesura átona, conforme as fórmulas sintéticas da notação numérica dos versos ${ }^{11}$. Quando estes compostos surgem em outros poetas, revelam-se esses versos, muitas vezes, sem grande especificidade, sujeitos que estão a flutuações rítmicas ${ }^{12}$.

Os cortes rítmicos aparecem raramente nos biexassílabos aqui estudados. Só nos lembramos de dois:

As mulheres - gentis, olhos meigos, serenos -;

adormece também, tranquilamente. Ao lado,

o seu cachimbo, a arder, como um vulcão, fumega...

mas sem, propriamente, terminação falsa dos versos ${ }^{13}$.

Nalguns dos biexassílabos de Bárbaros - sempre de cesura tónica, como dissemos - encontramos duas situaçồes em que os acentos secundários poderiam levar a certas alterações rítmicas. A primeira, são as falsas transições para os dodecassílabos tripartidos $12^{48}$, como em:

foge o Senhor do clan, os olhos como brasas

onde, apesar da acentuação na $4 .^{\mathrm{a}}$ e $8 .^{\mathrm{a}}$ sílabas, a pontuação (na posição da cesura tónica de um biexassílabo) delimitando o sentido das frases, demonstra claramente que não pode haver flutuação, devendo ler-se o verso, efectivamente, como um ritmo biexassilábico. Outros casos semelhantes que pudémos recensear:

E só tremiam quando, em noites de tormentas;

${ }^{11}$ Fórmulas sintética e analítica da notação numérica dos versos simples e compostos: Vid. T. g. d. v., vol. I, nº $12,56-57$. Na fórmula analítica, os ritmos acima têm a notação numérica seguinte: $\langle 4+4>+6,<4+4(1)>+6,6+<4+4>, 6(1)+<4+4>$ - onde, para clareza imediata, indicamos entre os sinais $<>$, os ritmos simples desdobrados.

${ }^{12}$ Para o conceito e exemplos de flutuação, vid., a T. g. d. v., vol. I, n. ${ }^{\circ}$ s 38, 40, 43-48, 50, 52, 63a,b11.

${ }^{13}$ Corte rítmico e terminação falsa: vid. T. g. d. v., vol. I, n. ${ }^{\circ}$ 5. Não consideramos que haja terminação falsa em: Ao lado, / o seu cachimbo... 
agora ria sempre, a fúnebre devassa;

enquanto vós cantais, por noites desoladas

onde a pontuação conscientemente colocada, com muito discernimento, impõe a leitura biexassilábica. Também nestes dois versos:

Usam garrida saia acima do joelho;

lembrando duma f 'rida o sulco ainda aberto;

o acento muito forte na $6 .^{\text {a }}$ sílaba do $1 .^{\circ}$ verso (sai) comportandose ele como acento de apoio para uma série de sílabas que o precede em próclise rítmica ${ }^{14}$ : usam garrida sai; e os acentos mais fraco ou fechado na $4 .{ }^{a}$ e na $8 .^{a}$ sílabas do outro, - não vêm, não podem vir alterar a manifesta forma biexassilábica que $o$ autor quiz dar àqueles metros. A segunda situação é constituída pelos casos em que a transição para um ritmo diferente, poderia ser admitida porque, em teoria, os versos podem passar por perfeitos dodecassílabos tripartidos, onde, além dos aspectos acentuais, a dupla pontuação, nalguns daqueles casos, não vem reforçar, privilegiando, uma pausa na $6{ }^{\mathrm{a}}$ sílaba:

e antes do sol romper no céu esplendoroso;

Para o suplício, então, eis que este avança agora;

Ele antevê na Morte o eterno Paraíso;

É que ele vai, enfim, viver entre mulheres;

Erram de noite, ao luar, as nossas tristes fadas.

Na prática, só admitimos estar-se em presença de uma transição voluntária para o ritmo simples dodecassilábico nos casos dos $2 .^{\circ}, 3 .^{\circ}$ e $4 .^{\circ}$ versos acima citados, pois que, pertencendo eles ao mesmo soneto, participam, pela lentidão imposta pelo ritmo $12^{48}$, de um propósito de harmonia expressiva onde a forma, a técnica formal, vem reforçar a expressão duma ideia, a descrição de um sentimento, etc. ${ }^{15}$ :

${ }_{14}$ Definição e exemplos de próclise rítmica: vid. T. g. d. v., vol. I, n. ${ }^{\circ} 13$.

15 Sobre o conceito de harmonia expressiva e técnica formal, vid. T. g. d. v., vol. I, n. ${ }^{\circ}$ s 77-79; e tb. diversos estudos de Amorim de Carvalho repertoriados no nosso ensaio bio-bibliográfico Amorim de Carvalho. No $1 .{ }^{\circ}$ Centenário do seu nascimento... atrás citado. 


\section{O ESCRAVO}

Certo Rei que mandava um povo rude e fero, à morte condenou - sentença esmagadora! um dia, em convulsões de raiva e desespêro, um escravo por quem desrespeitado fôra.

Para o suplício, então, eis que este avança agora, $12^{48}$ diante do olhar do Rei tremebundo e severo, como do cristianismo os mártires de outr 'ora, aureolado da luz dum sorriso sincero.

Ele antevê na Morte o eterno Paraíso,

e por isso o ilumina esse heróico sorriso, como, à noite, um clarão rasgando o céu opaco...

A sua religião promete-lhe prazeres:

É que ele vai, enfim, viver entre mulheres,

e lá, livre e feliz, pode fumar tabaco.

Aquele «então», como que prolongando a caminhada lenta para o suplício; e aquele «enfim» (conclusão de uma vida de escravo que desgraçadamente se arrastava) precedido do pensamento na Morte que é o «eterno Paraíso», antevistos ambos (aquela e este), presume-se, de longa data, - tudo isso, numa poesia que evoca igualmente, por contraste, em outros versos, a raiva feroz e a felicidade álacre da ideia da liberdade, - tudo isso, dizíamos, leva-nos a admitir que estamos em presença, aqui, talvez, de uma flutuação inscrita conscientemente pelo poeta, para possibilitar uma leitura, dos três versos referidos, subordinada ao lânguido dodecassílabo tripartido. Ficará, pois, ao critério do leitor, para esses três versos, a escolha entre a expressão rítmica do verso simples, o ritmo efectivo $12^{48}$, ou a do ritmo efectivo $6+6$, composto biexassilábico ${ }^{16}$.

Mas casos há em que o ritmo $12^{48}$ foi incluído conscientemente,

${ }^{16}$ A canónica das combinações heterométricas «para a sucessão de versos de medidas diferentes» resume as condições do bom acôrdo dos ritmos verbais definidas pela lei das relações matemáticas simples (a que já nos referímos) segundo a qual combinam excelentemente o hexassílabo de acentuação incerta 600 (e, portanto, o biexassílabo $6 \infty+6 \infty)$ e o verso simples dodecassilábico tripartido de ritmo efectivo 1248 (vid. T. g. d. v., vol. I, n. ${ }^{\circ}$ s 61-64). Os autores de estudos sobre métrica têm lamentavelmente confundido o dodecassílabo tripartido $1248 \mathrm{com}$ o biexassílabo ou alexandrino $6 \infty+6 \infty$, o que é imperdoável, pois o ritmo de um é completamente diferente do do outro. 
de forma bem manifesta, e sem flutuação possível, como harmonia expressiva, num conjunto biexassilábico. Verificamolo em dois versos:

e têm no andar os movimentos sedutores;

E no deserto, em sua tenda, à luz da lua

cada um deles num soneto diferente. A toada própria ${ }^{17}$ destes versos vem reforçar a ideia do movimento lento da mulher tropical e a modorrice numa tenda do deserto ardente:

Cobre-as da Graça ideal o resplendente nimbo, e têm no andar os movimentos sedutores $12^{48}$ do fumo que se evola ao sair dum cachimbo;

E no deserto, em sua tenda, à luz da lua, $12^{48}$ um moço rude e atleta, um nómada robusto, abraça uma mulher toda febril e nua...

Resumindo, podemos dizer que nos 172 versos dos 13 sonetos analisados no livro Bárbaros, encontrámos: a) um caso apenas de imperfeição rítmica (dada a intenção do autor em optar claramente pelo ritmo composto 6+6), mas cujo desvio (pela própria agudeza do ouvido do poeta) ficou recuperado para uma heterometria ${ }^{18}$ involuntária, certamente, mas heterometria

$\overline{17}$ A toada própria «de um verso é o seu ritmo»: $T$. $g . d$. v., vol. I, n. ${ }^{\circ} 4$.

18 A heterometria pode ser isossilábica: vid. T. g. d. v., vol. I, n. ${ }^{\circ} 62 \mathrm{~g}$. Heterometria isossilábica é conceito puramente formal que não aponta para o critério do bom acôrdo entre ritmos (por ex.: pentassílabos 52 e 51 ou 13 ou 3 que nós preferimos indicar pela fórmula mais abreviada 51-13-3; decassílabo de cesura átona 3(1)+6 e bipentassílabo de cesura tónica 51-13-3+51-13-3 ou 52+52 ). Mais interessante é o conceito de heterometria equilibrada que já diz respeito à boa combinação dos ritmos (por ex.: biexassílabos de cesura tónica e átona $6+6,6(1)+6$ e 6(2)+6). Outro caso de heterometria equilibrada: os dímetros decassilábico $4+6$ de cesura tónica, hendecassilábico 4(1)+6 de cesura átona simples, e dodecassilábico 4(2)+6 de cesura átona dobrada - que Amorim de Carvalho não indica explicitamente como sendo de heterometria equilibrada -, mas que nós consideramos como tal porque exprimem «um mesmo ritmo fundamental apesar das nuanças resultantes» (T. g. d. v., vol. I, n. ${ }^{\circ} 62 \mathrm{~h}$ ); recitem-se os seguintes versos compostos que extraímos, a título puramente experimental, de diversos poemas de Amorim de Carvalho, para mostrar a semelhança rítmica do conjunto: 
que não infringiu as regras do bom acôrdo dos ritmos verbais; b) cinco casos de flutuação possível em teoria, mas só em três deles provável por intenção do autor, embora mantendo em todos os versos citados a plena integridade e perfeição do ritmo biexassilábico dominante; c) dois versos de ritmo indiscutivelmente dodecassilábico, $12^{48}$, numa clara função de harmonia expressiva que é um dos aspectos da conceptualização da forma ${ }^{19}$.

Os restantes 10 sonetos dos Bárbaros foram compostos em versos decassilábicos. Note-se que se a toada própria do decassílabo heróico lhe dá um aspecto solene, "vigoroso e

$\begin{array}{ll}\text { a côr febril dos tapetes vermelhos } & 4+6 \\ \text { Quando se agita, como clarão, no a } & 4(1)+6 \\ \text { Não sei se há Deus. Sei que não somos nada } & 4+6 \\ \text { Lançam ao príncipe moedas de alto preço } & 4(2)+6 \\ \text { A bri-lhe a blusa. Ombros e peitos nus } & 4+6 \\ \text { Fixos em nada, se fixam no seu crânio } & 4(1)+6 \\ \text { e só ficasse um fantasma de flor - } & 4+6\end{array}$

No que respeita ao ritmo octossilábico: admitimos que, sem acentuação na 2.a sílaba, o octossílabo amoriniano 86 não está numa relação de heterometria equilibrada com o octossílabo 84 por parecer-nos que já não exprimem esses versos «um mesmo ritmo fundamental»:

labareda de som, fugindo $\quad 86$

E a serpente rubra e louca 84

(Amorim de Carvalho, «O Juízo Final»);

no entanto, com acentuação na 2.a sílaba, foi considerado por Amorim de Carvalho heterometricamente equilibrado com o 84, pois este metricista classificou o composto $826+84$ como regular (T. g. d. v., vol. I, n. $\left.{ }^{\circ} 26\right)$ :

Porque eu esperarei por ti $\mid$ até que morra ou enlouqueça $\quad 826+84$

Eu só é que te velo, imóvel 826

(Amorim de Carvalho, «O mito de Eva»)

Observação: não se deve confundir os conceitos diferentes de heterometria equilibrada e de bom acôrdo dos ritmos segundo a canónica das combinações heterométricas.

${ }^{19}$ Sobre o conceito de conceptualização da forma, vid. os já citados n. ${ }^{\circ}$ s 77-79 do vol. I da $T . g . d$. v.; e tb. diversos estudos de Amorim de Carvalho repertoriados no nosso ensaio bio-bibliográfico Amorim de Carvalho. No $1 .^{\circ}$ Centenário do seu nascimento... já citado. 
grave», o sáfico é duma «musicalidade ondulante» ${ }^{20}$. Aqui há também alguma coisa a comentar; embora nem sempre seja fácil relacionar os diversos esquemas teóricos sonoros, os esquemas rítmicos, com a forma rítmica que o poeta quiz efectivamente dar aos versos, interpretando esta forma rítmica à luz daqueles esquemas teóricos. E que há uma «grande parte de subjectividade [...] na condição de pronúncia dos versos»; no entanto, a «subjectividade [...] não há-de ser absolutamente arbitrária» pois «há-de decidir-se dentro das condições mesmas da versificação», isto é, «num certo âmbito de objectividade» de que resultou a formulação de leis ${ }^{21}$.

Em primeiro lugar, constata-se que um único soneto («Fanatismo») foi composto inteiramente em heróicos $\left(10^{6}\right)^{22}$. $\mathrm{O}$ soneto «Vermelho» comporta apenas um sáfico $(<4+4+2>$, na fórmula analítica da expressão numérica) a fechar o segundo terceto, rompendo assim com o ritmo que vinha de trás $(<6+4>$, na fórmula analítica do decassílabo heróico) - ruptura, parecenos que em uma harmonia bem expressiva de repetição $4+4+2$ desfiando-se até nas acentuações parcialmente secundárias $2+2+2+2+2$ :

Côr-tabu que enfeitiça! Côr que aterra! $\quad 10^{6}$

Côr do sangue a saltar duma ferida, $\quad 10^{6}$

que enleva e atrai como um tam-tam de guerra! $10^{48}$

numa harmonia imitativa ${ }^{23}$ bem marcada:

que enleva e atrai como um tam-tam de guerra!

Não consideramos heróico o último verso, pois que o acento em -mo um- é fraco e incaracterístico em relação a trai e tam, na $4 .{ }^{\mathrm{a}}$ e $8 .{ }^{\mathrm{a}}$ sílabas respectivamente. Os outros 8 sonetos,

\footnotetext{
${ }^{20} \mathrm{Os}$ aspectos rítmicos destes decassílabos foram estudados por Amorim de Carvalho in T. g. d. v., vol. I, n. ${ }^{\circ} 14$ (heróico) e n. ${ }^{\circ} 15$ (sáfico).

${ }^{21} T$. g. d. v., vol. I, n. ${ }^{\circ} \mathrm{s} 65,67$.

${ }^{22} \mathrm{Cf}$., no entanto, mais à frente, o comentário que fazemos relativamente ao verso: «debatem-se, febris e consternados».

${ }^{23}$ Harmonia imitativa: vid., para a boa compreensão deste conceito, o n. ${ }^{\circ} 77$ do vol. I da $T . g . d . v$.
} 
alternam heróicos e sáficos, segundo as boas regras das relações matemáticas simples, sem qualquer originalidade métrica para a poesia portuguesa.

Os cortes rítmicos, nos decassílabos de Bárbaros, pouco numerosos, sem novidades marcantes, também parecem, em geral, não fugir ao consagrado:

na guerra - ser feroz como um demente;

na paz - passar a vida entre prazeres;

Acampou sem coragem. Pelo espaço...

Apenas haverá uma observação a fazer ao primeiro verso acima. $\mathrm{O}$ corte rítmico, nitidamente imposto pela pontuação, tenderia a dar autonomia ao ritmo lírico heptassilábico (que é um ritmo muito forte):

na guerra - ser feroz como um demente

- o que perturbaria desagradavelmente a toada própria do decassílabo heróico (ritmo recitativo, este) que está na intenção do poeta ${ }^{24}$. A lei da força rítmica de totalização ${ }^{25}$ intervirá menos, talvez, neste caso, do que a lei da subordinação rítmica ou da assimilação rítmica ${ }^{26}$, para atenuar, na leitura, o corte rítmico, mantendo, consequentemente, o ritmo decassilábico que corresponde à totalidade do agrupamento silábico que há-de subordinar-se, assimilar-se ao ritmo global da poesia - ritmo esse que esteve, como dissemos, na intenção do poeta ao compôr este verso; para mais, o acento muito intenso em roz, na 6. ${ }^{\mathrm{a}}$ sílaba,

${ }^{24}$ Para a compreensão dos conceitos fundamentais que são os de ritmos lírico e recitativo, e o de ritmo forte, vid. T. g. d. v., vol. I, respectivamente n. ${ }^{\circ} \mathrm{s} 55-60$ e n. ${ }^{\circ} \mathrm{s}$ $11 \mathrm{~b}-\mathrm{c}, 67$.

25 Formulação da lei: «Dentro de qualquer agrupamento de sílabas métricas em cuja estrutura se contenham, como possíveis, duas ou mais formas rítmicas, torna-se dominante aquela que abranja a totalidade do agrupamento silábico» $(T . g . d$. v., vol. I, n. $\left.{ }^{\circ} 66\right)$.

${ }^{26}$ Formulação da lei: «Na entoação seguida de versos lançados em determinado ritmo, ou sequer na entoação intencional proposta dum certo ritmo, tendemos a subordinar-lhe ou a assimilar-lhe, tanto quanto possível, os casos de estruturas métricas defeituosas ou estruturalmente desviadas do ritmo referido» $\left(T . g . d\right.$. v., vol. I, n. ${ }^{\circ}$ 68). 
vem reforçar a subordinação rítmica, mantendo a toada própria decassilábica heróica e contribuindo também para a atenuação do corte rítmico indicado pelo travessão.

As terminações falsas dos versos são quase inexistentes no livro agora estudado; aparece uma, furtivamente, em:

O dromedário, já sequioso, neste braseiro imenso, segue vacilante

que não pode ser lido com alteração rítmica estabelecendo transição para:

O dromedário, já sequioso, neste braseiro imenso, segue vacilante

$8^{4}$

$6(1)+5$

onde damos logo conta do ritmo pentassilábico que destoa desagradavelmente do ritmo recitativo do soneto; é imperioso, no presente caso, seguir a técnica da «dicção corrida» fazendo «continuar o pensamento [...] até ao fim do verso para o qual esse pensamento foi transportado» ${ }^{27}$ :

O dromedário, já sequioso, neste $\rightarrow$

$\rightarrow$ braseiro imenso, segue vacilante

com pausa muito breve após a palavra neste.

Também não nos atardamos em situações como esta, no soneto «Agonia»:

como pairando sobre algum entêrro;

Geme a floresta como um ser humano

onde os acentos mais fortes nas 4 as $^{\text {as }}$ sibas indicam que os decassílabos devem, cremos, serconsiderados, preferencialmente, como sáficos, embora os acentos das $8 .{ }^{\text {as }}$ sílabas sejam fracos; não haverá, pois, flutuação. E, além do mais, os acentos, que consideramos secundários por pouco característicos e apagados,

$\overline{27}$ Desenvolvida explicação da dicção em situação de terminação falsa do verso, encontra-se no n. ${ }^{\circ}$, vol. I, da $T . g . d$. v. 
nas 6 . $^{\text {as }}$ sílabas dos versos acima, não vão interferir no ritmo sáfico, não tornam o verso «mole e indeciso entre sáfico e heróico»; se o autor da T. g. d. v. dá, nesta obra, diversos exemplos dessa imprecisão e indecisão entre os ritmos sáfico e heróico ${ }^{28}$, - entram mais manifestamente nesses casos, versos como:

Olho assombrada as minhas mãos vazias (Florbela Espanca)

com acentuações fortes nas $4 .^{\mathrm{a}}, 6^{\mathrm{a}}$ e $8 .^{\mathrm{a}}$ sílabas: neste sáfico, os acentos rítmicos nas $4 .^{\mathrm{a}}$ e $8 .^{\mathrm{a}}$ sílabas sofrem a concorrência duma acentuação não rítmica na 6 . $^{\mathrm{a}}$ sílaba de tonicidade equivalente à daquelas outras sílabas. Amorim de Carvalho evitou sistematicamente tais imperfeições. Nem consideramos estar nesta situação o $2 .^{\circ}$ verso do soneto «Indiano»:

moças formosas, peitos nus, esguias,

onde a pontuação lógica ${ }^{29}$, só por si, vem reforçar a acentuação já forte nas 4. ${ }^{\mathrm{a}}$ e $8 .^{\mathrm{a}}$ sílabas (tonicidade própria ou natural) ${ }^{30}$, aliás numa continuidade rítmica que procede do verso anterior, também ele de ritmo sáfico ${ }^{31}$, e seguindo-se-lhe um heróico onde a acentuação no ditongo ei (de chei) é, aqui, sim, incontornável:

À luz difusa da manhã cinzenta, $\quad 10^{48}$ moças formosas, peitos nus, esguias, $10^{48}$ conduzem cestos cheios de pimenta. $10^{6}$

Vejamos agora os seguintes versos extraídos de diversos sonetos:

debatem-se, febris e consternados;

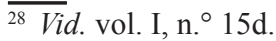

29 Pontuação lógica por oposição a pontuação rítmica ou de harmonia; vid., para este último conceito, $T . g . d$. v., vol. I, n. ${ }^{\circ} 67$.

${ }^{30}$ Vid. T. g. d. v., vol. I, n. ${ }^{\circ} 21$.

31 Lei das formas regulares ou do ritmo efectivo: «O ouvido aceita com agrado a forma cíclica ou regular representada pela repetição do mesmo número»; nesta lei «assenta o agrado da sucessão isométrica tradicional de versos tendo igual tipo métrico» (T. g. d. v., vol. I, n. $\left.{ }^{\circ} 61,61 \mathrm{a}\right)$. 
e o devorou... para ganhar coragem;

E mais além, mendigos repugnantes;

E os Mágicos, num ar de desconforto;

sinistramente, ouve-se ao longe o berro.

Se reputamos interessantes estes casos, é por considerarmos que os versos citados contêm possibilidades rítmicas que mais tarde serão conscientemente e sistematicamente introduzidas de jure e de facto por Amorim de Carvalho na poesia de expressão portuguesa. Retivemos para análise, apenas os casos que consideramos mais significativos e incontroversos - até pela existência duma pontuação rítmica (ou de harmonia) que vem como que solicitar claramente a pausa para uma cesura, fazendo flutuar a expressão verbal decassilábica $10^{6}$ ou $10^{48}$ para uma dicção em versos compostos irregulares de base hexassilábica: referimo-nos aos tetra-hexassílabos de cesura tónica e aos decassílabos de cesura átona dobrada ${ }^{32}$. As fórmulas numéricas dos versos acima referidos são as seguintes: para o tetrahexassílabo, $4+6\left(2 .^{\circ}, 3 .^{\circ}\right.$ e $5 .^{\circ}$ versos - este, com sinalefa do $1 .^{\circ}$ membro do verso composto no $2 .^{\circ}$ : sinistramen, te ouve-se ao longe o berro $)^{33}$; para o decassílabo amoriniano (de cesura átona dobrada), 2(2)+6 (1. ${ }^{\circ}$ e $4 .^{\circ}$ versos $)$ - cujas dicções, tal como se

32 Dissemos que estas formas rítmicas foram de facto introduzidas por Amorim de Carvalho na poesia de expressão portuguesa, primeiramente, porque a tradição do ritmo tetra-hexassilábico de cesura tónica (e também de cesura átona simples) se perdeu após o período literário trovadoresco; em segundo lugar, porque mesmo os trovadores (que, em Portugal, praticaram o tetra-hexassílabo por influência provençal) nem sempre o fizeram com boa técnica, confundindo, muitas vezes, cesura e acento tónico, além de não terem superado facilmente certas outras limitações métricas; e, enfim, e sobretudo, por ser Amorim de Carvalho o único poeta que, com consciência técnica, praticou intensivamente este ritmo na moderna poesia de língua portuguesa. Preferimos, consequentemente, denominar este verso composto irregular, pela expressão, que será sempre aqui utilizada, de tetrahexassílabo (terminologia adoptada por Amorim de Carvalho), em lugar das de decassílabo francês ou provençal (como também Amorim de Carvalho o denominou), pois ficaram estas últimas denominações desligitimadas pela importância que este ritmo adquiriu na obra poética deste poeta português e pelos estudos exaustivos que ele consagrou a este verso. Vid., por exemplo, T. g. d. v., vol. I, n. ${ }^{\circ}$ s 38-39, e, tb. de Amorim de Carvalho, o Depoimento para a história crítica do modernismo em Portugal, «Nova Renascença», Porto, n. ${ }^{\circ} 13$, janeiro-março de 1984, pág. 21. - O muito belo decassílabo de cesura átona dobrada é um ritmo puramente amoriniano, pelo que utilizaremos esta expressão para denominá-lo.

${ }^{33}$ Grafamos, neste exemplo, a pausa enfática que corresponde à cesura tónica. 
indicam, resultam, como dissemos, de flutuações relativamente aos esquemas rítmicos dominantes $10^{6} \mathrm{e} 10^{48}$. É fundamental ter presente no espírito o seguinte: para que o ritmo característico da forma composta 4+6 não se altere por acção da elisão rítmica «de que a cesura tónica é, em princípio, a indicação», há que fazer uma diálise rítmica técnica, ou seja, é necessário que a dicção separe nitidamente os dois componentes, tetrassílabo e hexassílabo; ora a pontuação nos versos de Amorim de Carvalho acima transcritos, vem precisamente favorecer e até impor a diálise rítmica técnica ${ }^{34}$. Os esquemas teóricos dos ritmos compostos naquelas formas dimétricas, exerceram, em Amorim, uma particular sedução - sedução que ele não esconde ao escrever na $T$. g. $d$. v.: «Pela fôrça da experiência estética do ritmo dos decassílabos franceses [o poeta refere-se aqui apenas à forma tetra-hexassilábica], aconteceu-nos a nós mesmo, na primeira e desprevenida leitura, dizer certos decassílabos portugueses na toada dimétrica daqueles, quando a estrutura dos versos se prestava a esta flutuação»; e exemplifica com versos de Antero de Quental:

Na mão de Deus, | na sua mão direita; $\quad 4+6$ Como a crian|ça em lôbrega jornada $\quad 4+6$

apesar, diz o autor da $T$. g. d. v., não ser esta a forma que estava «no propósito técnico dos dois versos de Antero». Todas estas razões nos levaram a admitir, portanto, uma já muito antiga tendência para a realização de formas rítmicas que Amorim de Carvalho introduzirá - repetimos - sistematicamente e com consciência técnica na sua poesia e na moderna literatura portuguesa. Não queremos, portanto, deixar de insistir na especial significação que se deverá atribuir a essas formas rítmicas que surgem logo nos primórdios da obra poética de Amorim de Carvalho. Consideramos, no entanto, que certos versos de Bárbaros, semelhantes ao último verso citado de Amorim e ao segundo de Antero, como:

$\overline{34}$ Diálise rítmica técnica no tetra-hexassílabo: vid. $T$. g. $d . v$., vol. I, n. ${ }^{\circ} 38 \mathrm{a}$. 
pedem, cantando, esmola aos viandantes...

não estiveram no espírito ou na intuição auditiva do poeta Amorim de Carvalho para uma flutuação $10^{6} / 4+6$, porque a expressão verbal e a pontuação não apontam claramente para essa possibilidade.

Para concluir esta primeira abordagem do ritmo na poesia de Amorim de Carvalho, podemos dizer: $1 .^{\circ}$, que os sonetos de Bárbaros retomam, em grande parte, ritmos já conhecidos na literatura portuguesa, seguindo os critérios tradicionais do bom acôrdo desses ritmos (biexassílabos e dodecassílabos tripartidos, decassílabos heróicos e sáficos); $2 .^{\circ}$, que o poeta teve desde muito cedo a intuição de ritmos originais, que ele, inovando, introduziu ou reintroduziu na literatura de expressão portuguesa, tais como os compostos 2(2)+6 (decassílabos amorinianos) e 4+6 (tetra-hexassílabos); e, $3 .^{\circ}$, que, desde muito cedo também, teve ele a boa compreensão de ritmos que realizou mais tarde, com uma frequência e com consciência técnica nunca igualadas por outros autores (portanto, também de facto inovando), como o composto $8^{4}+6$ - abrindo, nalguns casos, a possibilidade de flutuação para realizar esses ritmos em dicção claramente orientada, inclusive, pela pontuação, como se deduz do citado livro Bárbaros. Podemos ainda resumir, dizendo que os sonetos foram compostos (salvo algumas poucas flutuações admissíveis e raríssimas excepções), uns, no ritmo efectivo composto $6+6$, outros, nos ritmos $10^{6}$ e $10^{48}$ (ritmos propostos) ${ }^{35}$; no caso singular do verso composto $8^{4}+6^{24}$, temos dois ritmos efectivos em cada um dos componentes ${ }^{36}$ que podemos traduzir na fórmula analítica da expressão numérica: $<4+4>+<2+2+2>$; só dois versos foram inequivocamente redigidos no ritmo simples, efectivo, $12^{48}$. Nos sonetos em decassílabos, interpretamos 5 versos como ritmos propostos compostos: o 4+6 e o decassílabo amoriniano $2(2)+6$.

\footnotetext{
${ }_{35}$ Para a boa compreensão do que é ritmo e dos conceitos de ritmo proposto e ritmo efectivo, vid. T. g. d. v., vol. I, n. ${ }^{\circ} 4:$ : «...] ritmo é a repetição periódica (no tempo) dum fenómeno de qualquer modo diferenciado em si mesmo no tempo. Chamemos, ao que esse fenómeno é com sua diferenciação interna, ritmo proposto [...], ritmo proposto à repetição; e designemos esta repetição por ritmo efectivo». Acentuação do hexassílabo em sílabas pares: $T$. $g$. $d$. v., vol. I, n. ${ }^{\circ}$ 19d.
} 


\section{III - O ritmo lírico no livro Destino}

Do gôsto de Amorim de Carvalho pela heterometria - dentro daquelas condições objectivas definidas pelas leis do bom acôrdo dos ritmos verbais ${ }^{37}$-, fica já a prova na abundante criação poética que o autor reunirá no seu segundo livro de poesia: Destino, editado em 1939. Mas o poeta não repudiou os versos isométricos de que nos vai dar, igualmente, neste período - e em momentos posteriores da sua criação poética - grande número de belíssimos exemplos. Como indica o sub-título do Destino, parte das poesias incluídas neste livro foram publicadas dispersamente, em diversos periódicos, entre 1930 e 1937; outras, estavam inéditas. Ora, se em Bárbaros, Amorim de Carvalho se cingira, como vimos, ao ritmo recitativo, já no livro Destino vai ele utilizar o ritmo lírico em 9 das 45 composições poéticas que formam esta colectânea de inéditos e dispersos ${ }^{38}$. Cremos que os conceitos de ritmo recitativo e de ritmo lírico foram pela primeira vez definidos e exaustivamente estudados por Amorim de Carvalho. Denominam-se líricos os ritmos com «tendência espontânea para o canto», ritmos fortes possuindo, pois, toadas próprias particularmente cantantes; são, fundamentalmente, os

$\overline{37} \mathrm{O}$ estudo sério e sistematizado da heterometria no ritmo verbal (versos compostos irregulares, sucessão de versos heterométricos) constitui uma parte importante da versificação; a inclusão desse estudo nesta ciência, deve-se unicamente a Amorim de Carvalho ( $c f$. na T. g. d. v., vol. I, os n. ${ }^{\circ} \mathrm{s}$ 36-63). Isto (como muitos outros aspectos inovadores da teoria da versificação de Amorim de Carvalho) foi ignorado pelos historiadores e teorizadores portugueses da literatura, o que lhes tira a credibilidade. Autores estrangeiros têm-se referido, em obras de síntese, aos trabalhos de Amorim de Carvalho sobre versificação; como, por exemplo, citando de memória, o Professor Doutor José Domínguez Caparrós, da Espanha, o russo Mikhail Leonovich Gasparov, o brasileiro Massaud Moisés. Sintoma da esterilização progressiva do pensamento crítico e da investigação nas ciências humanas, os autores franceses actuais parecem desconhecer, du tout au tout, a obra daquele esteta português.

${ }^{38}$ A 4 dessas 9 poesias, deu Amorim de Carvalho o título de baladas, por seus temas fantásticos, de interrogação sobre a vida, o destino e a morte, onde o pensamento, desenvolvendo-se dentro de certo paralelismo formal e ideológico, se exprime em versos longos de ritmo efectivo muito cantante como são os bipentassílabos e os bieptassílabos. Há aqui um novo e belo tipo de balada que se afasta do antigo conceito estudado detalhadamente na $T . g . d$. v., vol. II, n. ${ }^{\circ} \mathrm{s} 117-118$. Dentro deste novo conceito de balada, teríamos de incluir algumas das muito belas produções de Alfredo Pimenta, poeta de mérito, além de notável historiador. 
eneassílabos tripartidos $\left(9^{36}=<3+3+3>\right)$, os heptassílabos $\left(7^{\infty}\right.$, de acentuação incerta), e os pentassílabos de acentuação par $\left(5^{2}\right.$ $=<2+3>)$ e de acentuação ímpar $\left(5^{1-13-3}=<1+4>\right.$ ou $<1+2+2>$ ou $<3+2>$ ). Se o poeta nunca mostrou inclinação pelo eneassílabo tripartido, cultivou, no entanto, com esmêro, desde muito cedo, os ritmos heptassilábico e pentassilábico, inclusive em suas formas compostas.

Consideremos, primeiramente, o ritmo pentassilábico de acentuação ímpar ${ }^{39}$, ritmo de grande vivacidade em que foram escritas duas composições incluídas no livro agora estudado; intitulam-se: «Luar de inverno» e «Balada do meu caminho». Este ritmo tomou, nessas duas poesias, a forma dominante do composto bipentassilábico, mas, na primeira delas, o poeta intercalou, em cada uma das suas 14 estrofes um verso pentassilábico (ritmo simples) conforme o seguinte esquema:
Arde a lua clara numa chama leve!
Como nos seduz
essa luz tão clara que parece neve!
neve tão brilhante que parece luz!

A tecnicidade, complexa, do pentassílabo, impõe que teçamos, desde já, algumas considerações gerais a seu respeito. O ritmo pentassilábico (qualquer que seja a sua acentuação: par ou ímpar) é um ritmo forte que se opõe à elisão rítmica «havendo [nele] até a tendência separativa [...] para a cesura átona, por um prolongamento paragógico [...], ou pelo hiato rítmico opondose à sinalefa [...], ou ainda por um silêncio de pausa enfática com valor métrico de completação, de preenchimento», $5(0)+5$, -o que tudo é explicado pela lei da oposição à elisão rítmica ou da força rítmica ou da diálise rítmica cuja formulação é a seguinte: «Quanto mais forte musicalidade ou quanto mais força melódica tenha um verso (ou ritmo), mais ele se opõe à sua elisão rítmica com outro verso (ou ritmo), sejam diferentes ou

\footnotetext{
$\overline{39} \mathrm{O}$ pentassílabo tem, como se disse, duas formas que não combinam bem entre si: a de acentuação ímpar e a de acentuação par; esta última não foi realizada por Amorim de Carvalho no livro Destino. Cf. T. g. d. v., vol. I, n. ${ }^{\circ} \mathrm{s} 20,63$ («Canónica das combinações heterométricas»).
} 
iguais os seus tipos rítmicos» ${ }^{40}$. Ora bem: Amorim, respondendo à natural exigência do ritmo pentassilábico, vai sistematicamente introduzir a cesura átona no composto bipentassilábico $-5(1)+5$ - marcando, assim, com clareza, a individualidade musical dos pentassílabos, sustentando, pois, nitidamente e com a maior naturalidade, a separação dos hemistíquios - individualidade musical e separação dos hemistíquios pedidas pela essência mesma deste ritmo. Levou, consequentemente, o poeta à maior perfeição técnica a construção deste ritmo composto:

É uma barca a lua, | meiga como a aragem, luminosa e alva!

prêsa sobre as ondas, | sem seguir viagem, como lírio aberto | pôsto numa salva! [«Luar de inverno»] $]^{41}$

Quando vier a noite, | densa, aterradora, de sandálias negras | plos caminhos fora,... [«Balada do meu caminho»]

Lidos os pentassílabos dois a dois, não há aqui cesuras tónicas nem possibilidade de sinalefas. Ao contrário, nos casos menos perfeitos, com cesura tónica como que forçando à elisão rítmica, o ritmo não será destruído nem sequer fundamentalmente alterado, mas a toada muito característica do forte ritmo pentassilábico ficará como que contrafeita ou constrangida numa leitura seguida de dois pentassílabos:

Vais seguindo, erran|te, um caminho incerto.

$$
\text { (Henrique Rosa) }
$$

Voa a pomba lon|ge em seu largo voo,

leva a flor da paz | presa no seu bico...

$$
\text { (experimental, de Amorim de Carvalho) }
$$

\footnotetext{
$\overline{40}$ Sobre o conceito de prolongamento paragógico, vid. T. g. d. v., vol. I, n. ${ }^{\circ}$ s $3,30 \mathrm{c}$. Exemplos de hiato rítmico opondo-se à sinalefa: mesma obra, vol. I, n. ${ }^{\circ} 30 \mathrm{c}$, onde também se expõe o conceito de pausa enfática. Vid., tb., na T. g. d. v., sobre os mesmos assuntos, o vol. I, n. ${ }^{\circ} 20 \mathrm{f}$. A formulação da lei da oposição à elisão rítmica encontra-se na mesma $T . g . d$. v., vol. I, n. ${ }^{\circ} 11 \mathrm{~b}$.

${ }^{41}$ Os títulos dos livros e das poesias de Amorim de Carvalho estão indicados entre parêntesis rectos: $[\ll \ldots »]$.
} 
quando o certo é que esse ritmo pede, naturalmente, diálise rítmica:

Vais seguindo, errante, | um caminho incerto

Voa a pomba longe $\mid$ em seu largo voo,

leva a flor da paz |... presa no seu bico...

Nesta minuciosa análise do verso pentassilábico em Amorim de Carvalho, é de notar a prática da ênclise rítmica ${ }^{42}$, - técnica utilizada, desde cedo, pelo poeta, que a introduziu na poesia «Luar de inverno»:

como se ele fosse $o \mid$ frio olhar dos mortos;

deixou ir em paz $o \mid$ descuidado vulto;

e em seus dedos tece a|quela rêde santa.

O ritmo efectivo do bipentassílabo de cesura átona não sofre desta subtilidade versificatória ${ }^{43}$.

Prosseguindo estas considerações sobre o ritmo pentassilábico, queremos chamar a atenção para alguns aspectos que refletem a preocupação do poeta pela realização do verso dentro dos melhores critérios da pureza rítmica.

Amorim de Carvalho teve o maior cuidado na construção do ritmo pentassilábico de acentuação ímpar, $5^{1-3-13}$ (verso acentuado na $1 .^{\mathrm{a}}$ ou na $3 .^{\mathrm{a}}$ ou na $1 .^{\mathrm{a}}$ e $3 .^{\mathrm{a}}$ sílabas), pois nunca intercalou neste ritmo a acentuação par, $5^{2 ;}$ caso contrário, alteraria a boa musicalidade do conjunto das composições poéticas. A deficiência apontada, que se verifica em diversos autores:

2. ${ }^{\mathrm{a}}$

Em tristes cuidados

1. ${ }^{\mathrm{a}} \quad 3 .^{\mathrm{a}}$

passo a triste vida;

$2 .^{\mathrm{a}}$

cuidados cansados,

$\overline{42}$ Cf. T. g. d. v., vol. I, n. ${ }^{\circ} 30$ a.

43 Fomos nós o primeiro a assinalá-la no poeta romântico António Pinheiro Caldas (Vid. nosso livro, já atrás citado, Dois escritores portuenses. O poeta António Pinheiro Caldas e Amorim de Carvalho, págs. 24-25). 
$1 .^{\mathrm{a}}$

vida aborrecida;

(Camões)

$3 .^{\mathrm{a}}$

Adorai montanhas,

$2 .^{\mathrm{a}}$

também as verduras,

$3 .^{\mathrm{a}}$

adorai desertos,

$2 .^{\mathrm{a}}$

e serras floridas;

(Gil Vicente)

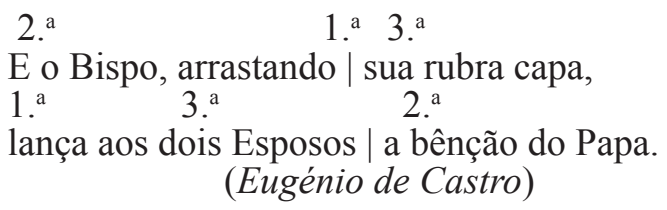

impõe uma leitura aos arrancos, desfeiando, manifestamente, a harmonia da composição poética na sua globalidade. Amorim terá o cuidado de não se afastar das boas regras, sempre fazendo incidir o acento rítmico nas sílabas ímpares:

Transparente, a noite, | como um grande rio que olho à minha roda, lembra-me uma bilha $\mid$ que estalou de frio $e$ que nos meus olhos $\mid$ se entornasse toda!

Param caminheiros, $\mid$ como por encanto, Lividos de assombros!

para sacudirem | o molhado manto

- o luar que levam, | sem saber, nos ombros!

[«Luar de inverno»]

Ó dos alvos seios, | lindos, de marfim, dize-me que ficas | a pensar em mim! 
Canta as minhas trovas, | canta-as com carinho, porque te ouça, ao longe, | pelo meu caminho!

Há no meu caminho | (que hei-de lá passar) uma curva triste | que nos faz chorar...

Lembra a Lua-Nova, | muito meiga e doce, quando toma a forma, | triste, duma fouce...

É naquele abraço | que dá volta ao muro dum silencioso | cemitério escuro... [«Balada do meu caminho»]

Apenas uma excepção ao que acabamos de afirmar:

$2 .^{\mathrm{a}}$

que pelos ribeiros $\mid \ldots$;

neste caso, o poeta consentiu que a única sílaba acentuada (aliás de tonicidade muitíssimo fraca: $p e$ ) coincidisse com sílaba par no hemistíquio; esta situação é corrigida pela subordinação rítmica (Vid. a lei atrás enunciada) numa dicção tendendo a tonizar a 1 . $^{\text {a }}$ sílaba, tonização essa que será reforçada ou evidenciada pela inserção de uma pausa enfática de compensação. Com esses processos, facilita-se o restabelecimento da harmonia rítmica:

A paisagem veste | de tristeza grata ! os fraguedos pinta!

E os fraguedos bebem | o luar de prata que [,] pelos ribeiros | onde cai - telinta !

Aquela lei da subordinação rítmica concorre, pois, com a lei da tonicidade posicional (que assim se formula: «O lugar de acentuação rítmica num verso reforça por si a tonicidade própria da sílaba nesse lugar» $)^{44}$, para reajustar ou acomodar versos que saiam dos esquemas rítmicos ideais.

Analisemos agora alguns outros detalhes da construção do ritmo pentassilábico nas duas poesias do Destino compostas neste sistema métrico.

$\overline{{ }^{44} T .}$ g. d. v., vol. I, n. ${ }^{\circ} 21 \mathrm{e}$. 
Ora -como vínhamos dizendo- se a acentuação ímpar é a regra sempre seguida (excepto num caso) pelo poeta, este, nos 64 bipentassílabos e 14 pentassílabos das duas poesias acima citadas, levou a perfeição rítmica ao ponto de excluir a possibilidade que uma sílaba naturalmente tónica (de tonicidade própria ou natural) coincidisse com sílaba par do verso ou do hemistíquio; apenas houve excepção nos três casos seguintes:

$2 .^{\mathrm{a}} 3 .^{\mathrm{a}}$

deixou ir em paz o $\mid . .$. ;

1. 2 . $^{\mathrm{a}}$

Vai pelas estradas $\mid . .$. ;

2. 3 . $^{\mathrm{a}}$

... que dá volta ao muro.

A acentuação forte da $1 .^{\mathrm{a}}$ sílaba do $2 .^{\circ}$ hemistíquio e das $3 .^{\text {as }}$ sílabas dos $1 .^{\circ}$ e $3 .^{\circ}$ hemistíquios, não deixa alterar substancialmente a toada própria (pentassilábica de acentuação ímpar) efectivada nas poesias; porque, nos $1 .^{\circ}$ e $3 .^{\circ}$ hemistíquios, as $2{ }^{\text {as }}$ sílabas vão integrar-se procliticamente no conjunto silábico apoiado na acentuação rítmica ímpar:

$$
\begin{aligned}
& 3 .^{\mathrm{a}} \\
& \text { deixou } \rightarrow \text { ir em paz o } \mid \ldots ; \\
& 3 .^{\mathrm{a}} \\
& \ldots \mid \text { que dá } \rightarrow \text { volta ao muro; }
\end{aligned}
$$

-aquelas 2. ${ }^{\text {as }}$ sílabas se atonizando ou tendendo a atonizar-se, numa dicção natural, em conformidade com a lei da subordinação rítmica. Dos três casos estudados, apenas no terceiro temos uma situação de concorrência nítida de um acento não rítmico (dá) com força tónica equivalente à do acento rítmico (o da sílaba ímpar: vol),- o que será um defeito. No $2 .^{\circ}$ hemistíquio, a acentuação muito fraca em pe (acento posicionado em sílaba par do hemistíquio, portanto acento não rítmico), atonizase completamente, dominada que está pela força tónica da precedente sílaba (Vai: acento posicionado em sílaba ímpar, portanto acento rítmico), -indo aquela sílaba atonizada integrarse, consequentemente, à extensão silábica que se apoia no último acento tónico (tra): 
$1 .^{\mathrm{a}}$

Vai pelas estradas | ...

Também é uma aplicação da lei da subordinação ou da assimilação rítmica. Pelo que temos exposto, vemos que Amorim de Carvalho soube, com maestria, impôr, em todos estes casos, uma forte tonicidade própria às sílabas que ocupam as posições dos acentos rítmicos (sílabas ímpares, pois se trata do ritmo pentassilábico $5^{1-3-13}$, que o poeta quiz realizar), - forte tonicidade própria tanto mais necessária que ela entra em concorrência com sílabas de acentuação não rítmica (porque na posição de sílabas pares); é a lei da exigência da força tónica do acento rítmico assim formulada: «A exigência da tonicidade própria ou natural dos acentos rítmicos principais é tanto maior quanto mais concorra uma acentuação rítmica secundária ou uma acentuação não rítmica» ${ }^{45}$. Pode pois afirmar-se, sem exitar, que Amorim (salvo raríssimas excepções) trabalhou com perfeição técnica o ritmo pentassilábico dando-lhe uma acentuação ímpar inequívoca.

Num único caso, encontramos um hemistíquio formado por uma extensão silábica de 4 sílabas átonas apoiadas na tónica final do metro pentassilábico:

\section{$5 .^{\mathrm{a}}$ que nas ventanias $\mid \ldots$;}

a «necessidade fisiológica de dicção» exige, nesta demasiada extensão atonizada, a tonização de uma das primeiras 3 sílabas, conforme explica a lei da partição acentual ou da tonização rítmica: "Numa extensão silábica de mais de quatro sílabas métricas, a necessidade fisiológica da dicção e o agrado auditivo levam espontâneamente a tonizar uma ou mais sílabas átonas internas, subdividindo essa extensão silábica em grupos apoiados nas respectivas sílabas tonizadas $\rangle^{46}$. Ora, como a tonização posicional, no contexto rítmico escolhido pelo poeta, não poderá

$\overline{45}$ T. g. d. v., vol. I, n. ${ }^{\circ} 21 \mathrm{e}$.

46 Vid. T. g. d. v., vol. I, n. ${ }^{\circ} 22 \mathrm{e}$. 
ser senão em sílaba ímpar ${ }^{47}$, a escolha recairá, mais naturalmente, na 3. ${ }^{\mathrm{a}}$ sílaba do hemistíquio (ven) repetindo o esquema rítmico que vinha sendo predominantemente efectivado (lei das formas regulares) $)^{48}$ :

Quando vier a noite, densa, aterradora, de sandálias negras plos caminhos fora,...

já irei distante, como a voz dum ai que nas ventanias abraçada vai... [«Balada do meu caminho»]

Mas pode-se-á admitir também a tonização da 1. a sílaba (que) seguida de pausa enfática de compensação, conforme a técnica de acomodação rítmica que já explicámos atrás:

que [,] nas ventanias $\mid$...

Preferimos a primeira solução.

Os 3 hemistíquios:

$e$ que nos meus olhos $\mid \ldots$;

e dos campanários, $\mid$...;

dum silencioso | ...;

apesar de aparentarem similitudes com o caso precedente, constituem, na realidade, situações diferentes: as sílabas $e$, dum têm tonicidade própria, embora fraca; elas vão adquirir, em ritmos de reduzida extensão como o pentassílabo (que é o mais curto verso simples $)^{49}$, «valor rítmico», porque «a mais ligeira acentuação interna, por contraste com uma reduzida amplitude

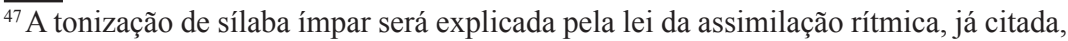
segundo a qual, «na entoação de versos [...] em determinado ritmo [...], tendemos [...] a assimilar-lhe [...] os casos de estruturas métricas defeituosas ou estruturalmente desviadas do ritmo referido».

48 Como já deu para aperceber ao longo deste estudo, situações há em que diversas leis da versificação concorrem para explicar um fenómeno rítmico, reforçando naturalmente a mais perfeita expressão melódica do verso.

${ }^{49}$ Para o bom entendimento do conceito de verso simples, vid. T. g. d. v., vol. I, n.os $8,12-20,24 a$.
} 
átona, ganha, por isso mesmo, valor de acentuação rítmica suficiente $\rangle^{50}$. Mas, se uma forte tonicidade própria coincidir com uma acentuação rítmica (isto é, em sílaba ímpar), - a promoção daquela tonicidade própria fraca a acento rítmico principal, já não tem razão de ser; é o que se verifica no seguinte exemplo extraído de «Luar de inverno»:

e de vagas linhas;

e neste, experimental, de nossa lavra:

dum silêncio môrno.

Por tudo o que atrás ficou dito, é lícito reconhecer que, se Amorim de Carvalho não inovou ao realizar, no livro Destino, o ritmo pentassilábico de acentuação ímpar (fundamentalmente na forma do verso composto regular que é o bipentassílabo: $\left.5(1)^{1-3-13}+5^{1-3-13}\right)$, - foi o poeta muito0 atento, nas poesias que acabámos de estudar, aos diversos aspectos da complexa técnica exigida para a concretização desse ritmo em sua melhor pureza musical.

Passaremos agora à análise do outro ritmo lírico também realizado por Amorim de Carvalho em Destino: referimonos ao ritmo heptassilábico, de toada ainda mais vincada do que a do pentassílabo. O heptassílabo é um ritmo muito forte, de acentuação incerta, que na fórmula sintética da notação numérica se indica por $7^{\infty}$. O poeta utilizou este ritmo, também muito cantante, em sete composições do livro acima citado, sendo quatro em versos heptassilábicos, e três delas em formas compostas bieptassilábicas às quais deu o título de baladas. A acentuação interna é determinada pelo acaso da sucessão das palavras, independentemente de exigências rítmicas específicas, como se pode ver nestes exemplos onde indicamos, em itálico, as sílabas acentuadas (unicamente os acentos dominantes):

Ó vento triste que passas, 2. ${ }^{\mathrm{a}}, 4{ }^{\mathrm{a}}$

Num murmúrio de desgraças! $3{ }^{a}$

$\overline{50}$ Vid. T. g. d. v., vol. I, n. ${ }^{\circ} 20$ c. 
que espalha folhas e rosas $\quad 2 .^{\mathrm{a}}, 4 .^{\mathrm{a}}$

pelo caminho adiante... $\quad 1 .{ }^{\mathrm{a}}, 4 .^{\mathrm{a}}$

- Rosas cheias de perfumes, $1 .^{\mathrm{a}}, 3$. $^{\mathrm{a}}$

que tu roubaste aos jardins; $\quad 4 .^{\text {a }}$

que vestem os reis e os numes $2 .^{\mathrm{a}}, 5$. $^{\mathrm{a}}$

[«Flores desfolhadas»]

O meu destino levou-me | por uma noite sem fim... 4. ${ }^{\mathrm{a}} \mid 4 .^{\mathrm{a}}$

... no seu riso de arlequim... ... 3 . $^{\mathrm{a}}$

Por uma noite sem fim | o Destino me levou. $\quad 2 .{ }^{a}, 4 .{ }^{a}{ }^{a} .^{a}$

E sobre o meu ombro, rin|do, a $L u$ a se debruçou... ${ }^{51} \quad 2 .{ }^{\text {a }}, 5$. $^{\text {a }} 2$ a $^{\text {a }}$

E numa voz que amedron|ta, e ao mesmo tempo arrebata $2 .{ }^{a}, 4 .{ }^{a} \mid 2 .{ }^{a}, 4 .^{a}$ diz, batendo no meu ombro| com a sua mão de prata $1 .{ }^{\mathrm{a}}, 3 .{ }^{\mathrm{a}} \mid 3 .{ }^{\mathrm{a}}, 5 .{ }^{\mathrm{a}}$

\section{[«Balada da Lua»]}

Arde no meu peito um sol $\quad 1 .{ }^{\mathrm{a}}, 5 .^{\mathrm{a}}$

que é um sol o coração. $\quad 3 .^{a}$

Morte, não venhas buscar-mo, $1 .{ }^{\mathrm{a}}, 4{ }^{\mathrm{a}}{ }^{\mathrm{a}}$

que ele queima a tua mão! 1. ${ }^{\mathrm{a}}, 3 .{ }^{\mathrm{a}}, 5 .{ }^{\mathrm{a}}$

[«Trovas»]

Rasguei os pés nos caminhos, | pelos temporais insanos, 2. ${ }^{\mathrm{a},}, 4{ }^{\mathrm{a}} \mid{ }^{\mathrm{a}} 1 .^{\mathrm{a}},{ }^{\mathrm{a}}$. $^{\mathrm{a}}$ procurando o meu desti|no, entre os destinos humanos. $\quad 3 .{ }^{\mathrm{a} \mid} \mid 1 .^{\mathrm{a}}, 4{ }^{\mathrm{a}}$

Destino que em vão chamei | quando chorei e sofri $2 .{ }^{\mathrm{a}},{ }^{5}{ }^{\mathrm{a}} \mid{ }^{\mathrm{a}} 1{ }^{\mathrm{a}},{ }^{\mathrm{a}},{ }^{\mathrm{a}}{ }^{\mathrm{a}}$

\section{[«Balada sem destino»]}

Do meu castelo de mármore $\mid$ perdi a chave doirada. $4 .{ }^{\mathrm{a}} \mid 2 .{ }^{\mathrm{a}}, 4{ }^{\mathrm{a}}$

Alguém acaso a encontrou ?| Por quem seria encontrada? 2. ${ }^{\mathrm{a}, 4} 4$. $\mathrm{a} \mid 4 .^{\mathrm{a}}$

É um castelo sem no|me, a fitar a solidão, 4. ${ }^{\mathrm{a} \mid} 3$. $^{\mathrm{a}}$

$\overline{{ }^{51} C} f$. o que dizemos, mais à frente, a propósito deste hemistíquio acentuado na 2 . $^{\mathrm{a}}$ sílaba. 
d'altas muralhas desertas $\mid \ldots \quad$ 1.. ${ }^{\mathrm{a}}, 4 .{ }^{\mathrm{a}} \mid \ldots$

[«Balada do meu castelo de mármore»]

À hora roxa do poente, $\quad 2 .^{\mathrm{a}}, 4 .^{\mathrm{a}}$

cheia de escuros ressábios, 1. ${ }^{a}, 4{ }^{\mathrm{a}}{ }^{\circ}$

com aquela côr pungente $\quad 3 .{ }^{\mathrm{a}},{ }^{5}{ }^{\mathrm{a}}$

que um cadáver tem nos lábios; 3 . $^{\mathrm{a}}$

\section{[《A saudade»]}

E quando a noite puser

sobre nós a fria mão,

2. ${ }^{\mathrm{a}}, 4 .^{\mathrm{a}}$

que $l u z$, que Sol, que alvorada, 2. ${ }^{\mathrm{a}}, 4 .^{\mathrm{a}}$

teremos para acender $\quad 2 .{ }^{\mathrm{a}}, 4{ }^{\mathrm{a}}{ }^{\mathrm{a}}$

\section{[《Inquietação»]}

Leiam-se estas transcrições, umas a seguir às outras, sem atentar no sentido das frases nem na sugestão da rima (que eliminamos parcialmente) para bem nos darmos conta da não fundamental interferência das acentuações internas no desenho do ritmo heptassilábico. No entanto, se se pode imprimir ao heptassílabo acentuações intencionais, como, por exemplo, $7^{24:}$

Eu trago os olhos cheiinhos

do verde intenso dos prados;

ou $7^{3}$ :

(Cacilda Celso)

\section{Cajueiro desgraçado}

a que fado te entregaste...

\section{(Silva Alvarenga) ${ }^{52}$}

$\overline{52}$ Estes exemplos e exemplos precedentes e outros que se darão neste estudo, de diversos autores, foram ou serão extraídos, pelo menos em grande parte, da $T . g . d$. v. de Amorim de Carvalho. Não vemos necessidade de ir esgaravatar em obras diversas para encontrar exemplos originais porque (além de redigirmos este estudo longe das nossas preciosas fontes de informação existentes na Biblioteca da Casa Amorim de Carvalho), «o conjunto dos poemas escolhidos - como escreveu Vera Vouga - para integrar a $[\ldots][T . g . d . v$.$] , amplo e orientado segundo os parâmetros$ fundamentais do ritmo, cuja escolha denota uma sólida erudição e um agudo critério estético, constitui por si só uma excelente antologia de poesia em Português»» 
(sem que se note nelas uma fundametal diferenciação rítmica em relação ao $7^{\infty}$, com uma ligeira característica própria para o $7^{3}$ :

Eu trago os olhos cheiinhos do verde intenso dos prados Ó vento triste que passas num murmúrio de desgraças Cajueiro desgraçado a que fado te entregaste que espalha folhas de rosas pelo caminho adiante),

- Amorim não se preocupou, neste sentido, com qualquer intencionalidade acentual. Podemos notar, num ou noutro momento, como, por exemplo, nas poesias «Saudade»e «Inquietação», uma reduzida série de três versos com a mesma acentuação interna, nas $2 .{ }^{\text {as }}$ e $4 .{ }^{\text {as }}$ sílabas:

a lua - branca princesa errando vai, com tristeza, no reino azul dos espaços;

consigo levam, de rastros e $d$ 'olhos postos nos astros, as nossas almas em prece?;

sem que se possa dizer - repetimos- que haja, aqui ou noutras ocasiões, por parte do poeta, a procura consciente em realizar o ritmo $7^{24}$. No entanto, depois de uma análise rápida da acentuação nos 267 versos e hemistíquios das 7 poesias de ritmo heptassilábico aqui estudadas, e considerando apenas os acentos que, muito de relance, nos pareceram dominantes ou mais característicos, -verificámos, $1 .^{\circ}$, que esses acentos caem predominantemente nas $4 .^{\text {as }}$ sílabas, tanto isoladamente como combinados com acentuações nas $1 .^{\text {as }}$ e $2 .^{\text {as }}$ sílabas; $2 .^{\circ}$, que as

\footnotetext{
(Recensões. Amorim de Carvalho -Teoria Geral da Versificação, 2 vols. Lisboa, Editorial Império, 1987, «Revista da Faculdade de Letras. Línguas e Literaturas», II série, vol. VII, 1990, pág. 283).
} 
acentuações mais frequentes se registam em tôrno dum eixo mediano da extensão verbal constituída pelas primeiras 6 sílabas do verso ou hemistíquio (56 acentuações nas $2 .^{\mathrm{a}}$ e $4 .^{\mathrm{a}}$ sílabas, 40 acentuações na 1. a e 4. ${ }^{\mathrm{a}}, 35$ na $4 .^{\mathrm{a}}, 34$ na 3. ${ }^{\mathrm{a}}, 30$ nas 2 . $^{\mathrm{a}}$ e 5. ${ }^{\mathrm{a}}$, 21 nas $3 .^{a}$ e $5 .^{a}$ sílabas). Chegar-se-ia, certamente, às mesmas conclusões, se análise idêntica à nossa fosse levada a cabo (se já não o foi), em poesias ou poemas do mesmo tipo rítmico, de outros bons poetas. Aqueles números refletem a natural e equilibrada colocação dos acentos na extensão heptassilábica; a boa técnica métrica, afinal, consistirá, neste ritmo, em não violentar sistematicamente essa equilibrada distribuição acentual.

A análise estatística a que procedemos, veio facilitar-nos a abordagem de certos aspectos da estrutura rítmica heptassilábica, nesta primeira significativa produção poética amoriniana. Podemos desde já afirmar a excelente musicalidade dada pelo poeta a este ritmo; pois são raríssimos os casos em que Amorim aceitou deixar passar uma deficiência métrica, -e quando isso aconteceu, é que, certamente, preferiu privilegiar, não a forma, mas a ideia, o pensamento (pensamento, ideia «em idealidade») que ele considerava ser a essência mesma da poesia: o ritmo e os outros aspectos formais (a rima, por exemplo) não entram na obra de arte senão como factores poetizantes, embora de primeira grandeza ${ }^{53}$. Vejamos.

1. ${ }^{\circ}$ ) A dupla acentuação final. Dois casos, não mais, de que nos apercebemos:

\section{6. ${ }^{\mathrm{a}} 7 .^{\mathrm{a}}$}

Os sonhos que os jardins sonham...-; ou quando, entre clarões baços...

Se é um evidente defeito da técnica métrica, a solução, para recuperar os versos, é lê-los de maneira que a $6 .^{a}$ sílaba tenda

\footnotetext{
${ }_{53}$ Conceito de poesia: Vid. T. g. $d$. v., vol. I, n. ${ }^{\circ} 1$; e diversos estudos de Amorim de Carvalho citados in Júlio Amorim de Carvalho, Amorim de Cavalho. No $1 .^{\circ}$ Centenário do seu nascimento. (Síntese biográfica). Uma bibliografia sobre versificação, já referido.
} 
a atonizar-se ligando-se procliticamente ao acento rítmico terminal:

Os sonhos que os jardins $\rightarrow$ sonham...-;

ou quando, entre clarões $\rightarrow$ baços...

E se o $2 .^{\circ}$ verso tem ainda o senão de nele encerrar outras 2 sílabas juntas acentuadas naturalmente (tonicidade própria: quan, -do en-):

2. ${ }^{\mathrm{a}} \quad 3 .^{\mathrm{a}}$

ou quando, entre clarões baços;

o $1 .^{\circ}$ ganha beleza no próprio paralelismo ideológico inserido na frase:

Os sonhos que os jardins $\rightarrow$ sonham...-;

repetição que favorece, cremos, o apoio proclítico da $6 .^{\mathrm{a}}$ na $7 .^{\mathrm{a}}$ sílaba e, consequentemente, a atonização da $6 .{ }^{\mathrm{a}}$ sílaba, - anulandose assim, em larga medida, o defeito técnico que apontáramos. 2. $\left.{ }^{\circ}\right) \mathrm{O}$ caso do hemistíquio:

$3 .^{\mathrm{a}} 4 .^{\mathrm{a}}$

Pelo céu ria-se a Lua, | ...

Tem duas sílabas seguidas acentuadas, a 3. a e a 4. a , o que, em teoria pura, é um defeito métrico, criando uma indecisão rítmica. A compensação estaria em fazer apoiar procliticamente a $3 .^{a}$ na $4 .^{a}$ sílaba, no seguimento, aliás, de dois hemistíquios de acentuação dominante na $4 .^{\mathrm{a}}$ sílaba:

Pelo céu $\rightarrow$ ria-se a Lua, | no seu riso de arlequim...

Mas temos para nós, que há, aqui, a vontade manifesta do poeta em imprimir ao hemistíquio em causa, através duma conceptualização da forma, uma harmonia bem expressiva: 
a alegria, um riso alegre, sonoro, -essa harmonia expressiva convertendo-se em harmonia imitativa pelos sons mesmos abertos e incisivos das acentuações dominantes nesse e nos outros hemistíquios que iniciam a «Balada da Lua»:

O meu Destino levou-me | por uma noite sem fim...

Pelo céu ria-se a Lua $\mid$ no seu riso de arlequim...

O último verso citado prevaleceu no espírito do autor que o retomou para, com as mesmas sonoridades, dar o fecho à «Balada»:

... naquela noite sem fim...

Pelo céu ria-se a Lua, no seu riso de arlequim...

3. $\left.{ }^{\circ}\right)$ A aparente acentuação única na 2. ${ }^{a}$ sílaba de certas formas heptassilábicas: $7^{24}$ ou $7^{25}$. Encontrámo-la em oito casos, nas 7 poesias heptassilábicas que estamos a analisar. A amplitude átona de 4 sílabas exige (conforme a lei da partição acentual, como ficou atrás explicado) a acentuação da $4 .{ }^{a}$ ou $5 .{ }^{a}$ sílabas, o que indicamos em itálico, nas seguintes transcrições:

... | debaixo do meu olhar;

... $\mid$ não sondes os seus segredos;

ou porque $t u$ me esqueceste;

... | perdi-me no meu caminho;

... ao vento sem direcção;

... fechado no seu mistério;

passavam em labaredas;

... | a porta do meu castelo.

A tonicidade própria, embora fraca, das palavras monossilábicas: meu, seus, tu, sem, seu, em ${ }^{54}$, leva para elas, com a maior naturalidade, a segunda acentuação rítmica das formas heptassilábicas.

4. ${ }^{\circ}$ ) Os doze casos do $7^{2}$ :

$\overline{54}$ Sobre a tonicidade própria, embora fraca, dum certo número de palavras como aquelas aqui citadas, vid. T. g. d. v., vol. I, n. ${ }^{\circ} 20 \mathrm{c}$. 
de plagas misteriosas;

mais belas do que os cetins; ou

mais belas do que os cetins;

... | a Lua se debruçou; ou

... | a Lua se debruçou;

Que buscas nas solidões | ...; ou

Que buscas nas solidões |...;

... | a minha desolação; ou

... | a minha desolação;

... em forma de coração ${ }^{55}$;

Silêncios, que pareciam | ...; ou

Silêncios que pareciam $\mid \ldots$;

... | pavores de encantamento; ou

... | pavores de encantamento;

Que mantos de vendavais; ou

Que mantos de vendavais;

Que sonhos incompreendidos;

na febre que nos consome; ou

na febre que nos consome;

na escura desolação; ou

na escura desolação.

Há também nestes ritmos, a necessidade fisiológica de acentuar uma das sílabas da longa extensão átona de 4 sílabas:

\section{2. ${ }^{\mathrm{a}} \quad 7 .^{\mathrm{a}}$}

de plagas misteriosas;

etc.;

no entanto, nestes casos, a acentuação (que incidirá obrigatoriamente nas $4 .^{\mathrm{a}}$ ou 5 . $^{\mathrm{a}}$ sílabas), terá que ser solicitada segundo critérios diversos dos que presidiram àquelas acentuações nos oito ritmos $7^{24}$ e $7^{25}$ precedentemente analisados. Haverá, aqui, compensações a fazer para acomodar uma metrificação menos perfeita. As flutuações foram indicadas em itálico. Outro modo para compensar, na dicção, a desagradável extensão de 4 sílabas

\footnotetext{
$\overline{55} \mathrm{Na}$ pronúncia de Portugal, em geral, o o fechado acentuado, em coração, com valor
} de u, daria uma cacofonia desagradável. 
átonas, é, nestes casos, abrir pausas de compensação, ficando o grupo heptassilábico dividido em um dissílabo e um tetrassílabo «separados por cesura átona, mas que o ritmo forte heptassilábico, sempre recobre e assimila para uma totalidade rítmica $\rangle^{56}$.

$\left.5 .^{\circ}\right) \mathrm{O}$ heptassílabo aparentemente acentuado apenas na 5. ${ }^{\mathrm{a}}$ sílaba. 4 versos e hemistíquios foram, em aparência, metrificados na forma $7^{5}$, isto é, como se também comportassem amplitudes átonas de 4 sílabas -o que exigiria, para uma diç̧ão corrente, a tonização de uma das átonas até à $3 .^{\text {a }}$ sílaba. Mas também nestes casos não estamos em presença de verdadeiros $7^{5}$, pois que as $1 .{ }^{\text {as }}$ e $2 .^{a}$ sílabas, por suas tonicidades próprias, serão naturalmente acentuadas:

... | à luz do luar funéreo;

... que eu alevantei sem ti!...

em meditações d'asceta;

em recordação formosa.

Os ritmos heptassilábicos resolvem-se, afinal, em perfeitos $7^{15}$ ou $7^{25}$.

$\left.6^{\circ}{ }^{\circ}\right)$ Não se encontra nos heptassílabos de Amorim a forma bastante defeituosa que outros poetas não evitaram, como o $7^{1 \text { : }}$

Tanto que me pareceu

(Sá de Miranda)

com uma extensão átona de 5 sílabas; nem tampouco o deficiente $7^{5}$, como:

Se por me cobrar saís

(Gregório de Matos)

com acentuação na 5. ${ }^{a}$ sílaba apenas, -exigindo, já o sabemos, um e outro verso, a tonização forçada, em sílaba à escolha (no primeiro exemplo, na $3 .^{a}$ ou $4 .^{a}$ ou $5{ }^{\text {a; }}$ no segundo, na $1 .^{a}$ ou $2 .^{a}$ ou 3. ${ }^{\mathrm{a}}$ ), conforme a lei da partição acentual (ou da tonização rítmica),

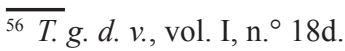


«processo que reconduz [o verso] a acentuações [tecnicamente] boas do heptassílabo»» ${ }^{57}$.

Os bieptassílabos das três «Baladas» aqui estudadas, foram compostos, indiferentemente, com cesura átona e tónica, esta sem ou com sinalefa indicada em itálico. Exemplos:

Por uma noite sem fim $\mid$ o Destino me levou.

E sobre o meu ombro, rin $\mid d o, a$ Lua se debruçou...

E numa voz que amedron|ta, e ao mesmo tempo arrebata, diz, batendo no meu ombro | com a sua mão de prata:

A alma triste da noite | põe traições nos arvoredos...

Há pavor nos seus mistérios: | não sondes os seus segredos ! [«Balada da Lua»]

Rasguei os pés nos caminhos, | pelos temporais insanos, procurando o meu desti|no, entre os destinos humanos.

Busquei no céu uma estrêla: | fui atrás dela sòzinho...

Fugiu a estrêla do céu: | perdi-me no meu caminho... [«Balada sem destino»]

Do meu castelo de mármore $\mid$ perdi a chave doirada.

Alguém acaso a encontrou? |Por quem seria encontrada?

E um castelo sem no|me, $a$ fitar a solidão,

d'altas muralhas desertas | em forma de coração.

Vinham, dos lúgubres pátios, | pavores de encantamento, como ruflar d'asas mortas $\mid$ agitadas pelo vento... [«Balada do meu castelo de mármore»]

Apenas na última poesia surge, por excepção, um único verso com cesura átona dobrada:

... már(mo-re) | ...

cuja fórmula sintética da notação numérica é: 7(2)+7. Em:

Há pavor nos seus misté(rios) $\mid \ldots$

Vinham, dos lúgubres pá(tios), $\mid \ldots$

$\overline{57}$ T. g. d. v., vol. I, n. ${ }^{\circ} 18 \mathrm{~d}$. 
considerámos que a cesura átona é simples, atribuindo, portanto, aos dois compostos a notação numérica 7(1)+7. A indiferente utilização, na mesma composição poética, das cesuras átona e tónica vem do facto que «Em razão da força rítmica dos hemistíquios [heptassilábicos] ${ }^{58}$, a cesura tónica [...] não produz elisão rítmica, e o ouvido não nota notável diferença entre os compostos de cesura tónica $[\ldots]$ e os $[. .$.$] de cesura átona» { }^{59},-\mathrm{O}$ que é explicado pela já enunciada lei da força rítmica ${ }^{60}$.

Terminamos aqui o estudo do ritmo lírico, em que foram compostas algumas das poesias incluídas no citado livro Destino, editado em 1939. Podemos, como última conclusão, dizer, pois, que Amorim de Carvalho trabalhou o ritmo heptassilábico, desde cedo, com esmêro. Se o poeta esteve, provavelmente, mais atento à perfeição formal do ritmo pentassilábico que à do ritmo heptassilábico, -foi, no entanto, neste último ritmo lírico que ele compôs maior número de poesias e talvez com mais elevação temática, - poesias que podem ser apontadas como formalmente belas.

Não terá passado desapercebido ao leitor que nós unicamente nos interessámos pelo que, no ritmo verbal, é objectivável. Recusámos, consequentemente, avançar estéreis considerações sobre o que Amorim de Carvalho -num livro notável da história da crítica em Portugal ${ }^{61}$ - chamou «aquela parte do ritmo que é «espírito», que não é «letra», que não se «mostra», que não se sabe o que seja, que é tudo quanto quisermos, mas que não é nada para a crítica».

\footnotetext{
$\overline{58}$ Como se sabe, o ritmo heptassilábico é um ritmo muito forte, mais forte do que o pentassilábico.

${ }^{59}$ T. g. d. v., vol. I, n. ${ }^{\circ} 27$.

${ }^{60} \mathrm{Cf}$. o que, sobre o mesmo fenómeno rítmico, dissemos atrás, a respeito do bipentassílabo.

${ }^{61}$ Através da obra do sr. António Botto. (Análise crítica), Porto, 1938. Neste livro, Amorim de Carvalho mostrou a pobreza rítmica da versificação de Botto, e demonstrou a reduzidíssima originalidade temática deste autor fortemente sugestionado, até ao plágio, em grande parte pela leitura da obra do escritor hispanoamericano E. Gómez Carrillo.
} 